\title{
Macroinvertebrate diversity in fragmented Alpine streams Implications for freshwater conservation
}

\author{
Journal Article \\ Author(s): \\ Monaghan, Michael T.; Robinson, Christopher T.; Spaak, Piet; Ward, James V. \\ Publication date: \\ 2005-12 \\ Permanent link: \\ https://doi.org/10.3929/ethz-b-000030664 \\ Rights / license: \\ In Copyright - Non-Commercial Use Permitted \\ Originally published in: \\ Aquatic Sciences 67(4), https://doi.org/10.1007/s00027-005-0787-0
}




\title{
Research Article
}

\section{Macroinvertebrate diversity in fragmented Alpine streams: implications for freshwater conservation}

\author{
Michael T. Monaghan ${ }^{1,2, *}$, Christopher T. Robinson ${ }^{1}$, Piet Spaak ${ }^{1}$ and James V. Ward ${ }^{1}$ \\ ${ }^{1}$ Swiss Federal Institute of Aquatic Science and Technology (Eawag), Department of Limnology, \\ Überlandstrasse 133, CH-8600 Dübendorf, Switzerland; and Swiss Federal Institute of Technology (ETH), Zürich, \\ Switzerland \\ ${ }^{2}$ Present address: Department of Entomology, The Natural History Museum, Cromwell Road, London, SW7 5BD, \\ United Kingdom; and Department of Biological Sciences, Imperial College, Silwood Park, Ascott, SL5 7PY, \\ United Kingdom
}

Received: 12 November 2004; revised manuscript accepted: 19 April 2005

\begin{abstract}
Lakes and reservoirs disrupt the longitudinal connectivity of streams, considerably affecting benthic macroinvertebrate assemblages and diversity. Changes in assemblage composition within fragments can result from habitat alteration and reduced dispersal between fragments. We investigated the effects of habitat fragmentation in 10 Alpine streams, examining 69 taxa of benthic macroinvertebrates from 22 sites in fragmented and freeflowing streams. Total taxon richness ( $\alpha$-diversity) ranged from 6 to 27 in individual sites, and total richness was not significantly affected by fragmentation. However, Ephemeroptera and Diptera (excluding Simuliidae) richness was significantly reduced in stream fragments. Beta-diversity indicated a high degree of taxon turnover among sites within streams, but was not significantly different be-
\end{abstract}

tween fragmented and unfragmented streams. Characterizing the biological, physiological, and ecological traits of Ephemeroptera showed that communities in reservoirfragmented streams had a higher affinity for fine sediments, increased temperatures, and reduced current velocity. Taxon assemblages in fragments were not nested subsets of unfragmented site assemblages. Thus, species turnover and species replacement in fragments is common, suggesting that most taxa are able to freely disperse among fragments. We suggest that habitat alteration was the primary cause of changes in assemblage structure in these streams. Consequently, habitat-based conservation is likely to be successful in maintaining populations of all but the weakest dispersers.

Key words. Biodiversity; dispersal; Ephemeroptera; habitat fragmentation; nestedness; aquatic insects; species traits.

\section{Introduction}

Habitat fragmentation is a major threat to the preservation of biodiversity (Wilcox and Murphy, 1985; Fahrig, 2003). The loss of habitat, isolation of fragments, and increase in edge from habitat fragmentation can reduce

* Corresponding author phone: +44 (0)20 7942 5609; fax: +44 (0)20 7942 5229; e-mail: m.monaghan@nhm.ac.uk Published Online First: August 29, 2005 species diversity and change community composition through a variety of processes (Klein, 1989; Newmark, 1991; Saunders et al., 1991; Robinson et al., 1992; Andren, 1994; Margules et al., 1994). Like most ecosystems, streams are subject to habitat fragmentation which can result in a loss of biodiversity of benthic macroinvertebrates (Zwick, 1992; Allan and Flecker, 1993; Dynesius and Nilsson, 1994; Ward and Tockner, 2001). The construction of dams and reservoirs alters the natural physical structure of streams and rivers by creating 
an area of standing water and by changing, reducing, or halting downstream flow. A similar alteration of physical connectivity occurs naturally by the formation of lakes. Lakes are formed by landslides, glacial activity (e.g., ice-scour, cirque) and deposition (morainedammed lakes, kettle lakes), volcanism, and tectonic action. These lakes and reservoirs represent chemically (Kling et al., 2000) and biologically (BreitenmoserWürsten and Sartori, 1995; Willis and Magnuson, 2000) distinct habitats that fragment streams into discrete flowing reaches.

Habitat change downstream of lakes and reservoirs is well documented, including the effect these changes can have on benthic fauna (Ward and Stanford, 1979; Ward, 1976; Robinson and Minshall, 1990; Richardson and Mackay, 1991; Vinson, 2001). Ecologically, this could be classified as a kind of edge effect, where habitat is altered immediately at the outflow. Less well studied is the effect that reduced connectivity among flowing water reaches may have on organisms (Neraas and Spruell, 2001). Upstream reaches may become more isolated because of reduced dispersal across standing-water habitat (e.g., Monaghan et al., 2001), but the extent to which dispersal among fragments affects community composition is not well understood for benthic macroinvertebrates (e.g., Caudill, 2003).

We studied macroinvertebrate assemblages in $10 \mathrm{Al}-$ pine streams to assess the effects of habitat fragmentation on biodiversity. Three streams were free-flowing and seven were fragmented by lakes, reservoirs, or both. Our first objective was to test the hypothesis that diversity was reduced in individual stream fragments (sites) and in fragmented streams as a whole. Taxon richness was compared among sites within streams ( $\alpha$-diversity) and among different streams ( $\gamma$-diversity) to determine whether sites above and below lakes or reservoirs were significantly different from sites in free-flowing streams. Our second objective was to determine whether the ecological traits of communities were affected by habitat fragmentation. Here we examined differences in assemblage characteristics of mayflies (Ephemeroptera) by evaluating 22 biological, physiological, and ecological species-traits (after Tachet et al., 2002). Finally, we aimed to assess the relative importance of dispersal among habitat fragments in determining assemblage structure. We measured taxonomic nestedness (Patterson and Atmar, 1986; Patterson, 1987) of study sites as a proxy for testing whether dispersal among reaches is an important determinant of reachscale community structure.

\section{Methods}

\section{Study sites}

The study was conducted in the headwaters of the Rhine, Inn, and Ticino rivers in the Swiss Alps, where an abundance of streams, lakes, and reservoirs allowed us to study the ecological effects of habitat fragmentation in stream ecosystems. Eight of the 10 study streams had 2 sampling sites, located above and below a lake, a reservoir, or along an unfragmented length of stream (Table 1, Fig. 1). Samples were taken $\sim 150 \mathrm{~m}$ above and below lakes to minimize the effects of the lake outlet itself. Below reservoirs, samples were taken between $500 \mathrm{~m}$ (Ritom) and $2300 \mathrm{~m}$ (Livigno) to minimize reservoir outflow effects. Two streams had three sampling sites: above, between, and below two standing water bodies (Fig. 1). The three sites at Cadagno/Ritom were located above Lake Cadagno, between Lake Cadagno and Lake Ritom (a reservoir that is an enlarged lake), and below Lake Ritom; the three sites

Table 1. The 10 streams of the study, in which the 22 study sites were located. Two streams had three sampling sites and were divided into distinct reaches: the upper and lower reaches of Jörisee and the Cadagno and Ritom reaches of Cadagno/Ritom.

\begin{tabular}{|c|c|c|c|c|}
\hline Major drainage & Stream & Stream Type & $\begin{array}{l}\text { Upper/lower } \\
\text { elevation (m) }\end{array}$ & $\begin{array}{c}\text { Distance between } \\
\text { sampling sites }(\mathrm{m})\end{array}$ \\
\hline \multirow[t]{5}{*}{ Rhine } & $\begin{array}{l}\text { Schwellisee } \\
\text { Jörisee }\end{array}$ & Lake-fragmented & $1935 / 1930$ & 350 \\
\hline & Upper Jöri & Lake-fragmented & $2525 / 2495$ & 550 \\
\hline & Lower Jöri & Lake-fragmented & $2495 / 2320$ & 975 \\
\hline & Marmorera & Reservoir-fragmented & $1700 / 1450$ & 7750 \\
\hline & Arosa & Free-flowing & $1940 / 1930$ & 375 \\
\hline \multirow[t]{5}{*}{ Ticino } & Bianco & Lake-fragmented & $2080 / 2076$ & 525 \\
\hline & Cadagno/Ritom & & & \\
\hline & Cadagno & Lake-fragmented & $1940 / 1900$ & 1075 \\
\hline & Ritom & Reservoir-fragmented $^{\mathrm{a}}$ & $1900 / 1780$ & 4500 \\
\hline & Muesa & Free-flowing & $2225 / 2200$ & 280 \\
\hline \multirow[t]{3}{*}{ Inn } & Minor & Lake-fragmented & $2340 / 2325$ & 375 \\
\hline & Livigno & Reservoir-fragmented & $1910 / 1660$ & 10000 \\
\hline & Julierpass & Free-flowing & $2310 / 2205$ & 625 \\
\hline
\end{tabular}

a Ritom is a reservoir that is an enlarged natural lake. For the analyses it was considered a reservoir. 


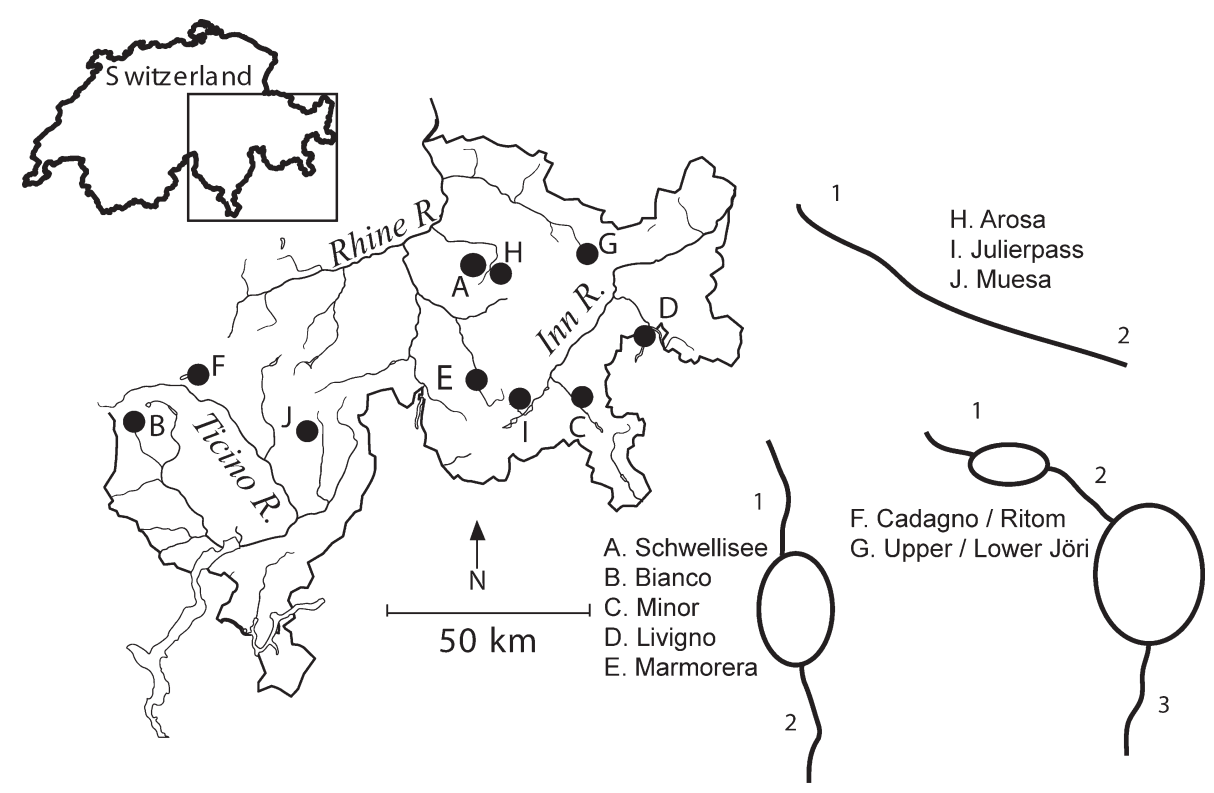

Figure 1. Map of the study sites in Switzerland, showing respective upstream (1) and downstream (2, 3) sampling locations.

at Jöriseen were located among two lakes (Upper and Lower Jöri; Fig. 1). There were no tributaries entering any of the study streams between sample sites. All sites were in alpine tundra above tree line, except for both sites at Marmorera and the lower sites at Livigno and Ritom which were located in alpine forest. Elevation ranged from 1450 to $2525 \mathrm{~m}$ a.s.l. and altitudinal differences between upper and lower sites ranged from 4 to $250 \mathrm{~m}$ (Table 1).

\section{Macroinvertebrate collection and identification}

Benthic macroinvertebrates were sampled semi-quantitatively using a $100-\mu \mathrm{m}$ mesh kick net. Sampling was standardized to $5 \mathrm{~min}$ and all habitat and substrate types within a 50-m reach of stream were sampled. Riffles, runs, and pools were typical habitats, and substrata included moss, organic detritus, and sediment ranging from silt and clay to large boulders. Samples were preserved in the field with formalin (4\%) or ethanol (70\%). Each site was sampled at least 3 times, once each in spring, summer, and autumn in either 1998 or 1999. Eleven of the 22 sites were sampled once in mid-winter: both sites at Schwellisee, Bianco, Cadagno, Marmorera, and Arosa; the upper site of Livigno; and lower sites of Moesa and Julierpass. The other sites were inaccessible in winter because of snow cover and avalanche danger. Inclusion of taxa observed only in the winter samples did not significantly affect the overall results, thus all sampling periods were used in the analysis.

In the laboratory, all invertebrates were hand-picked using a dissecting microscope $(10 \times)$. Two very large sam- ples were first split in half by eye. Taxon richness was determined for each sampling site ( $\alpha$-diversity) and for each stream ( $\gamma$-diversity) by pooling all seasonal samples. Ephemeroptera, Plecoptera, and Trichoptera were identified to species with few exceptions. Within the Plecoptera, most Isoperla, Leuctra, Nemoura, and Protonemura were identified at the genus level because of taxonomic uncertainty for larvae (V. Lubini, pers. comm.). Within the Trichoptera, we identified 6 species of Rhyacophila but a number of other Rhyacophila were classified sensu stricto (Waringer and Graf, 1997). Sericostoma (Trichoptera) was identified only to genus. Within the Diptera, we identified Blephariceridae and Simuliidae to species; most others were identified to family, with the exception of Atherix, Dicranota, Hexatoma, Rhabdomastix, and Rhypholophus. We grouped Oligochaeta (Annelida), Elmidae (Coleoptera), and Hydracharina, and we observed only one species of Gammaridae (Amphipoda) and Planariidae (Turbellaria).

\section{Taxon richness and turnover}

We first tested for the effect of drainage basin (Rhine, Inn, Ticino) on assemblage structure using cluster analysis to group sampling sites. We calculated pairwise Euclidean linkage distances from the presence-absence data matrix and then created a clustering tree using Ward's (1963) method. Sampling sites within streams clustered together in 6 of 10 cases and the presence of a fragmenting feature did not appear to influence whether or not sites clustered together (data not shown). The 3 sites of Cadagno/Ritom clustered together, as did the 2 sites in 
Marmorera, Livigno, Bianco, Arosa, and Julierpass. Neither sites nor streams were clustered by major drainage, indicating no drainage effect on assemblage structure. Therefore, subsequent analyses were carried out on the combined data set.

We used 1-way ANOVA on log-transformed data to compare $\alpha$-diversity among sites in free-flowing streams $(n=6)$, lake-fragmented sites $(n=11)$, and reservoirfragmented sites $(n=5)$. Post-hoc testing was carried out using Tukey's honest significant difference test for unequal sample sizes (Zar, 1984). We analyzed each major taxonomic group (Ephemeroptera, Plecoptera, Trichoptera, and Diptera) separately using the same analysis, including analysis of Diptera with and without Simuliidae. The latter analysis was done to remove the potentially confounding effect of high Simuliidae abundance below lake outlets and because they were the most highly resolved group within the Diptera. We used 1-way ANOVA to compare $\gamma$-diversity between fragmented $(n=7)$ and unfragmented $(\mathrm{n}=3)$ streams. For this analysis, the upper and lower reaches of Jörisee and Cadagno/Ritom were considered as separate streams, thus $\alpha$-diversity from the middle sites of these streams was used for 2 calculations of $\gamma$-diversity. All analyses were conducted with Statistica v. 5.1

Taxon turnover ( $\beta$-diversity) between sample sites in each stream was measured using the Sorenson index $C$ : $C=2 \mathrm{j} /(\mathrm{a}+\mathrm{b})$, where $\mathrm{j}=$ the number of taxa found in both sites, $a=$ the number of taxa in site $a$, and $b=$ the number of taxa in site b (Magurran, 1988). $C$ ranges from 0 to 1 , with a value of 1 indicating identical taxa composition and a value of 0 indicating sites share no taxa in common. We compared $C$ among lake, reservoir, and unfragmented sites using ANOVA on arcsine(square-root) transformed data (Zar, 1984).

\section{Species traits}

Using the methods of Tachet et al. (2002), the mayfly (Ephemeroptera) fauna of each study site was characterized using 22 biological, physiological, and ecological traits. After analysis of all samples, taxa were found to fall into natural breaks in abundance and so were placed into categories of 1 (= low abundance, no more than $1-5$ individuals per sample), 2 (= moderate, 6-50 individuals), or 3 (= high, $>50$ individuals). When abundance varied among seasons, we used the highest recorded value for the year. For each taxon, we multiplied its abundance category by the given affinity for each of 2-8 modalities within each trait (Tachet et al., 2002). Taxa examined included Baetis, Ecdyonurus, Epeorus, and Rhithrogena. We compared the relative frequencies of a given trait modality (abundance $\times$ affinity) among site categories (unfragmented, lake-fragmented, reservoir-fragmented) using MANOVA on transformed (arcsine(square-root)) data and Tukey's honest significant difference test with unequal sample sizes.

\section{Nestedness}

The degree of nestedness was examined using the Temperature Calculator of Atmar and Patterson $(1993 ; 1995)$. The calculated system "temperature" $(\mathrm{T})$ reflects the degree of order present in presence-absence matrices and ranges from $\mathrm{T}=0$ (perfectly nested) to $\mathrm{T}=100$ (random). Sites are considered to be nested when depauperate sites comprise a nested subset of species in richer sites, and nested assemblages in recently fragmented habitats are hypothesized to result from extinction (Blake, 1991; Taylor and Warren, 2001).

\section{Results}

\section{Macroinvertebrate richness and turnover}

We identified 69 taxa, including 12 Ephemeroptera, 12 Plecoptera, 20 Trichoptera, 20 Diptera, and 5 others: $\mathrm{Cre}$ nobia alpina (Planaria), Gammarus fossarum (Amphipoda), Elmidae (Coleoptera), Hydracarina (Acarina), and Oligochaeta. Taxon richness of individual sites $(\alpha)$ ranged from 6 to 27 (see Appendix I). There were no significant differences in total $\alpha$-diversity among lake-fragmented sites (17.9 \pm 6.2$)$, reservoir-fragmented sites $(21.0 \pm 3.5)$, and unfragmented sites $(22.0 \pm 2.5$; mean $\pm 1 \mathrm{SD})$ (Table 2). Ephemeroptera $\alpha$-diversity was lower in lakefragmented sites $(2.6 \pm 1.4)$ than in reservoir-fragmented sites $(5.0 \pm 0.7 ; p=0.019)$ and unfragmented streams (4.5 $\pm 1.9 ; p=0.05$; Table 2$)$. Diptera $\alpha$-diversity was not significantly different among site types; however, Diptera $\alpha$-diversity was lower in lake-fragmented streams (2.8 \pm 1.0) than unfragmented streams when Simuliidae were excluded ( $4.3 \pm 0.8 ; p=0.007$ ) (Table 2). There was no significant difference between upstream and downstream site richness in fragmented streams (data not shown). Total $\gamma$-diversity ranged from 18 to 33 and was not significantly different among streams $\left(\mathrm{F}_{2,9}=0.385 ; p=0.691\right)$ (Table 3).

Taxon turnover within streams $(C)$ averaged 0.65 across the whole study; i.e., paired sites within streams often shared $50 \%$ or fewer taxa. However, $C$ was not significantly different among stream types (Table 3 ). A single taxon, Rhyachophila sensu stricto, was found only in unfragmented streams, while 27 taxa ( 40\% of the total diversity) were observed only in stream fragments.

\section{Species traits}

Analysis of mayfly traits indicated significant differences between lake-fragmented and reservoir-fragmented 
Table 2. Mean (SD) taxon richness among sites and ANOVA results for all taxa combined and for the 4 major groups. Shared superscript letters within a row indicate a lack of significant difference (Tukey's post-hoc test $p<0.05$ ).

\begin{tabular}{|c|c|c|c|c|c|c|c|c|}
\hline \multirow{3}{*}{$\begin{array}{l}\text { Taxon } \\
\\
\text { All }\end{array}$} & \multicolumn{6}{|c|}{ Mean taxon richness of sites } & \multirow{3}{*}{$\begin{array}{l}\text { ANOVA } \\
F_{2,19} \\
1.55\end{array}$} & \multirow{3}{*}{$\begin{array}{l}p \\
0.240\end{array}$} \\
\hline & \multicolumn{2}{|c|}{ Lake-fragmented } & \multicolumn{2}{|c|}{ Reservoir-fragmented } & \multicolumn{2}{|c|}{ Free-flowing } & & \\
\hline & 17.9 & (6.2) & 22.0 & $(2.5)$ & 21.0 & (3.5) & & \\
\hline Ephemeroptera & 2.6 & $(1.4)^{\mathrm{a}}$ & 5.0 & $(0.7)^{\mathrm{b}}$ & 4.5 & $(1.9)^{\mathrm{b}}$ & 5.87 & 0.010 \\
\hline Plecoptera & 3.7 & $(1.7)$ & 3.8 & $(0.8)$ & 4.8 & $(0.8)$ & 1.36 & 0.280 \\
\hline Trichoptera & 3.9 & $(2.7)$ & 3.8 & $(2.9)$ & 4.2 & (1.9) & 0.03 & 0.970 \\
\hline Diptera $^{1}$ & 5.2 & $(1.6)$ & 5.2 & $(2.3)$ & 6.0 & $(0.9)$ & 0.54 & 0.590 \\
\hline Diptera $^{2}$ & 2.8 & $(1.0)^{\mathrm{a}}$ & 3.6 & $(0.5)^{\mathrm{ab}}$ & 4.3 & $(0.8)^{\mathrm{b}}$ & 6.13 & 0.009 \\
\hline
\end{tabular}

1 all Diptera.

2 excluding Simuliidae.

Table 3. Total taxon richness in streams $(\gamma)$ and assemblage similarity $(\mathrm{C})$ within streams.

\begin{tabular}{lll}
\hline Stream type & $\gamma$ & $\mathrm{C}$ \\
\hline Lake-fragmented & & \\
$\quad$ Schwellisee & 27 & 0.58 \\
Bianco & 18 & 0.80 \\
Minor & 26 & 0.32 \\
Cadagno & 30 & 0.64 \\
$\quad$ Upper Jöri & 18 & 0.67 \\
Lower Jöri & 31 & 0.49 \\
$\quad$ Mean & 25 & 0.61 \\
Reservoir-fragmented & & \\
Livigno & 23 & 0.72 \\
Marmorera & 29 & 0.65 \\
Ritom & 31 & 0.65 \\
$\quad$ Mean & 28 & 0.67 \\
Free-flowing & & \\
Arosa & 23 & 0.85 \\
Julierpass & 27 & 0.71 \\
Moesa & 33 & 0.68 \\
$\quad$ Mean & 28 & 0.75 \\
\hline
\end{tabular}

streams $\left(F_{28,8}=31338, p<0.001\right)$ (Table 4$)$. Mayfly assemblages in reservoir-fragmented sites had higher mean affinities for 1) diapause or quiescence; 2) feeding on fine sediments and microorganisms; 3 ) feeding by crushing; 4) thermophylic stenothermy $>15^{\circ} \mathrm{C}$; 5) silt and clay microhabitats; and 6) lentic conditions. No significant differences occurred between free-flowing streams and either type of fragmented stream.

\section{Nestedness}

Assemblage structure was nested among the 22 study sites $(T=31.4 ; p<0.001)$; however, fragmented sites were not nested subsets of unfragmented sites (Fig. 2). For instance, the first 2 rows of the packed data-set were fragmented sites (Lower Jöri-3, Minor-2), and the two most isolated sites (Cadagno-1 and Upper Jöri-2) were not the least taxon-rich. The frequency distribution of taxa among sites generated by the Temperature Calcula-

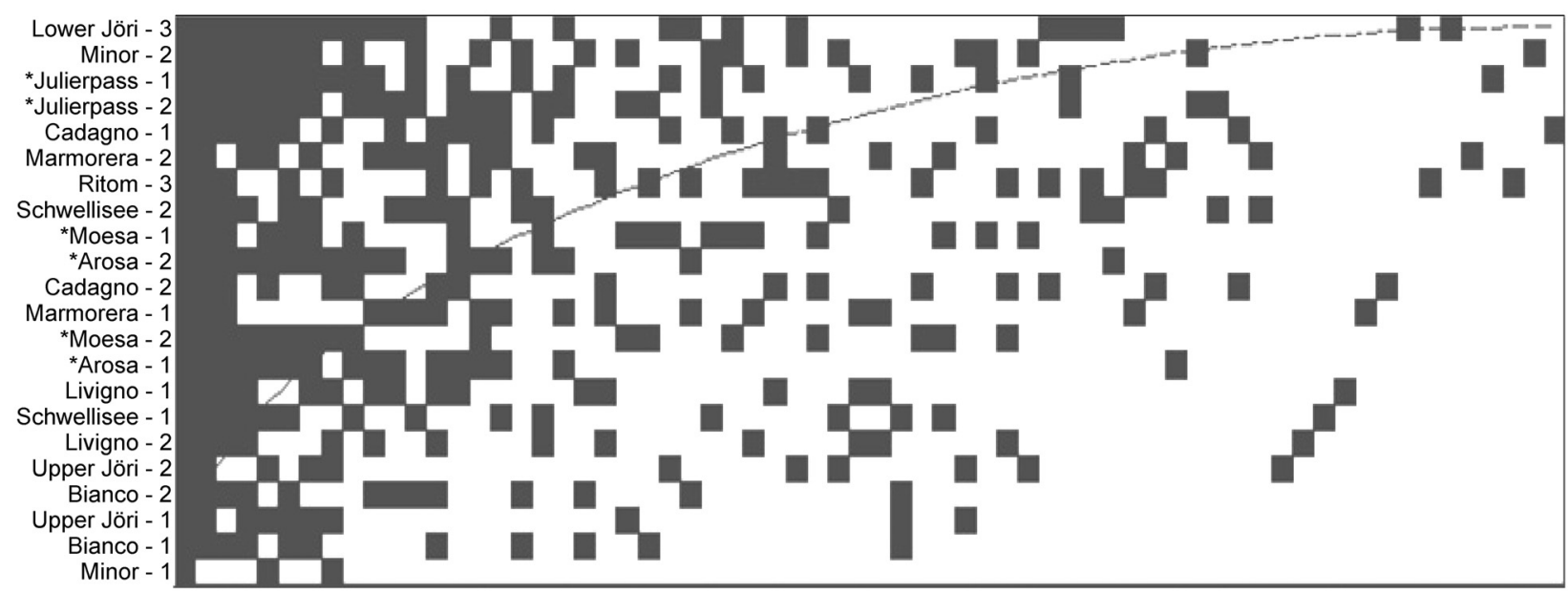

Figure 2. The packed data matrix of nested $(\mathrm{p}<0.001)$ taxon assemblages in the 22 study sites. An asterix $(*)$ indicates sites that were in free-flowing streams. Four taxa were found in all sites (Baetis alpinus, Crenobia alpina, Chironomidae, and Oligochaeta) and therefore are compressed into a single (left-most) column. 
Table 4. Mean trait scores for the mayfly communities in 3 stream types. Scores were calculated by multiplying abundance category (see text) by taxon affinity for each possible characteristic within each trait (from Tachet et al., 2002). Statistical differences among stream types (MANOVA, $p<0.05$ ) are marked with * and superscript letters shared within a row indicate a lack of significant difference (Tukey's posthoc test $p<0.05$ ). For brevity, only the first two traits are fully reported, showing the scores for each characteristic of the mayflies in the study. Thereafter, only significantly different characteristics are shown for individual traits.

\begin{tabular}{|c|c|c|c|}
\hline $\begin{array}{l}\text { Trait } \\
\text { charactersitic }\end{array}$ & $\begin{array}{l}\text { Lake-fragmented } \\
\qquad(n=11)\end{array}$ & $\begin{array}{l}\text { Reservoir-fragmented } \\
\qquad(n=5)\end{array}$ & $\begin{array}{l}\text { Free-flowing } \\
\quad(n=6)\end{array}$ \\
\hline \multicolumn{4}{|l|}{ Max. body size } \\
\hline 5-10 mm & $0.51(0.14)$ & $0.41(0.05)$ & $0.43(0.09)$ \\
\hline $10-20 \mathrm{~mm}$ & $0.49(0.14)$ & $0.59(0.05)$ & $0.57(0.09)$ \\
\hline \multicolumn{4}{|l|}{ Life cycle duration } \\
\hline$\leq 1 \mathrm{yr}$ & $0.88(0.06)$ & $0.87(0.02)$ & $0.84(0.03)$ \\
\hline$>1 \mathrm{yr}$ & $0.12(0.06)$ & $0.13(0.02)$ & $0.16(0.03)$ \\
\hline \multicolumn{4}{|l|}{ Resistance } \\
\hline diapause* & $0.03(0.04)^{\mathrm{a}}$ & $0.09(0.04)^{b}$ & $0.06(0.04)^{\mathrm{ab}}$ \\
\hline \multicolumn{4}{|l|}{ Diet } \\
\hline $\begin{array}{l}\text { fine sediments } \\
\& \text { microorganisms* }\end{array}$ & $0.01(0.01)^{\mathrm{a}}$ & $0.02(0.03)^{b}$ & $0.03(0.02)^{\mathrm{ab}}$ \\
\hline \multicolumn{4}{|l|}{ Feeding group } \\
\hline collector-gatherer* & $0.04(0.06)^{\mathrm{a}}$ & $0.12(0.07)^{b}$ & $0.12(0.08)^{\mathrm{ab}}$ \\
\hline $\begin{array}{l}\text { Temperature } \\
\text { stenotherm }>15^{\circ} \mathrm{C}^{*}\end{array}$ & $0.03(0.04)^{\mathrm{a}}$ & $0.06(0.04)^{\mathrm{b}}$ & $0.07(0.06)^{\mathrm{ab}}$ \\
\hline $\begin{array}{l}\text { Microhabitat } \\
\text { silt, clay* }\end{array}$ & $0.01(0.01)^{\mathrm{a}}$ & $0.02(0.01)^{\mathrm{b}}$ & $0.02(0.01)^{\mathrm{ab}}$ \\
\hline $\begin{array}{l}\text { Current speed } \\
\text { none* }\end{array}$ & $0.01(0.02)^{\mathrm{a}}$ & $0.03(0.02)^{b}$ & $0.04(0.03)^{\mathrm{ab}}$ \\
\hline
\end{tabular}

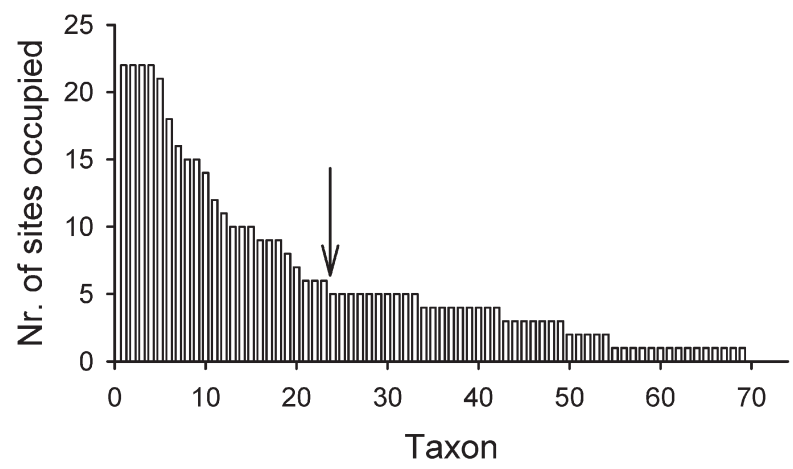

Figure 3. Frequency distribution of the 69 taxa among the 22 sampling sites. The taxa to the right of the arrow were defined as rare by their occurrence in fewer than $25 \%$ of sites.

tor showed that 46 of the 69 taxa were "rare", (sensu Gaston, 1994) occurring in fewer than 6 (25\%) of the sample sites (Fig. 3).

\section{Discussion}

\section{Macroinvertebrate richness}

Our results strongly suggest that assemblage response to fragmentation was dependent on the taxon considered, and that lakes and reservoirs had very different effects. This was particularly true for mayfly assemblages, which were less diverse in lake-fragmented streams, and functionally altered in reservoir-fragmented streams. Mayfly species largely missing from lake-fragmented sites included Ecdyonurus alpinus, E. picteti, and Rhithrogena endenensis. Sensitivity to environmental change and habitat alteration is well documented for the mayflies (Brittain, 1982; Bauernfeind and Moog, 2000); but the lack of significant difference in $\alpha$-diversity above and below lakes suggests there were no downstream effects. Other evidence also suggests that alpine lake outlets are not distinctly different habitats within a stream compared with lowland lake outlets (Hieber et al., 2002). Species distributions are very much influenced by elevation (Ward, 1994; Sartori and Landolt, 1999), but lake-fragmented and free-flowing study sites were all at comparable elevations. This was not the case for reservoir sites, which tended to be at lower, more species-rich elevations. For example, Baetis melanonyx, B. rhodani, and E. venosus are sub-alpine species, typically found only below 2000 $m$ a.s.l. (Sartori and Landolt, 1999). Thus, elevation may have confounded our results from reservoir-sites, but not from lake-fragmented sites.

Trait analysis found that mayfly assemblages in reservoir-fragmented streams were better adapted to low current velocities. This difference was exemplified by the higher overall affinity for fine sediment microhabitat and high temperature $\left(>15^{\circ} \mathrm{C}\right)$ stenothermy. Notably, this result was mostly due to changes in the relative abundance 
of taxa (e.g., increased abundance of Ecdyonurus in reservoir-fragmented streams) rather than the presence or absence of different species. It follows that habitat change caused by reservoir outflows probably persisted into our sampling reaches. A large amount of research has demonstrated significant effects of reservoirs on Ephemeroptera assemblages (reviewed by Brittain and Saltveit, 1989) and the persistence of such effects downstream (e.g., Ward, 1976). Habitat change results from alterations in flow pattern and discharge that lead to changes in current, substrate, water quality, and thermal regimes (Ward and Stanford, 1979). The only detectable change in trait representation (based on post-hoc analysis) was between lake and reservoir sites, highlighting (1) the increased effect of habitat alteration by reservoirs, and (2) the high variability among free-flowing streams.

Lower Diptera richness resulted from the absence of Limoniidae, Psychodidae, and Tipulidae in lake-fragmented sites, although Hexatoma was more commonly observed in fragments. Interestingly, the first 3 taxa are detritus $(>1 \mathrm{~mm})$ feeders and Hexatoma is a predator (Tachet et al., 2002), suggesting a change in resource availability may be responsible for the change in Diptera composition. No similar change in trophic guilds was found for other taxonomic groups such as Plecoptera and Trichoptera. Inclusion of Simuliidae negated any significant difference in Diptera richness among sites, highlighting the effects of taxonomic resolution on such analysis. Simuliidae may have obscured patterns in lake-fragmented streams because 5 taxa (Prosimulium latimucro, Simulium cryophilum, S. monticola, S. nölleri, and $S$. tuberosum) were not found in free-flowing streams (Appendix I). The reason for this is not clear. On the one hand, alpine lakes rarely occur singly in a drainage basin, but rather in clusters or chains (e.g. paternoster lakes) because of the glacial processes that form them (Ritter et al., 1995). Thus, upstream lake outlet habitat may influence our results. However, our upstream sampling sites had no upstream lake or were $>1000 \mathrm{~m}$ downstream of the nearest lake, and not all of these Simuliidae species are lake outlet specialists.

\section{Spatial turnover and nestedness of taxa}

One aim of our study was to assess the role that isolation of fragments may have on assemblage structure in habitat fragments. Despite the confounding effects of downstream habitat alteration and elevation (discussed above), the data provide some means to assess the effect of fragment isolation. Estimates of $\beta$-diversity indicated large amounts of taxon turnover within and among streams. Mean $C$ was 0.65 across the whole study, showing paired sites within streams often shared $50 \%$ or fewer taxa. Additionally, macroinvertebrate assemblages were nested. While this is a common attribute of most species assem- blages (Wright et al., 1998), aquatic invertebrates have been seen as an exception to this pattern (Boecklen, 1997; Malmqvist et al., 1999). Boecklen (1997) considered aquatic invertebrates to be so diverse (e.g., insects, mollusks, crustaceans) that patterns in nestedness were obscured. More recently, Malmqvist and Hoffsten (2000) found that distributions were nested only when Ephemeroptera, Plecoptera, Trichoptera, and Simuliidae were analyzed separately.

What was unexpected in our study was that taxa in fragmented sites were not nested subsets of taxa in unfragmented sites. Instead, the uppermost 2 sites in the packed matrix (Fig. 2) were lake-fragmented sites, sites in free-flowing streams were distributed throughout the matrix, and the two most isolated fragments were not the lowermost sites. Nestedness of fragments within intact sites would suggest that extinction from fragments without recolonization ("faunal relaxation") was an important determinant of macroinvertebrate assemblage structure (Blake, 1991; Newmark, 1991). This was not the case in our study streams. The large number of "rare" taxa (46 out of 69) and the occurrence of 27 taxa found only in fragmented streams provides more evidence that taxon turnover was high and that assemblage structure was highly variable.

Taken together, the high spatial turnover of taxa and the lack of nestedness of fragments suggest that most taxa are able to disperse among fragments. It follows that habitat choice or suitability is a more important factor for determining assemblage structure than the isolation of fragments. While such a generalization overlooks several species-specific examples of limited dispersal in aquatic invertebrates (Bohonak and Jenkins, 2003), we suggest it is a reasonable hypothesis for most of the community, based on our data set.

Many studies have concluded that macroinvertebrate assemblage structure in streams is closely related to localscale habitat characteristics such as current, substrate, and temperature (Minshall, 1984; Douglas and Lake, 1994; Allan, 1995; Richards et al., 1997; Downes et al., 1998; Minshall and Robinson, 1998; Voelz and McArthur, 2000; Burgherr and Ward, 2000; Melo and Froehlich, 2001; Sponseller et al., 2001). An overriding assumption is that most or all members of the regional species pool are able to disperse over large areas in a "propagule rain" and that more local processes determine their presence or absence in particular habitats (i.e., habitat filters, sensu Poff, 1997). An interesting exception to this pattern in our study may be mayflies. Dispersal among sites can be an important factor in maintaining populations (Caudill, 2003) and some mayfly species may disperse poorly in fragmented streams (Monaghan et al., 2001). Thus, fragment isolation may partially explain the reduced richness of Ephemeroptera we observed in lake-fragmented streams. 


\section{Implications for freshwater conservation}

A large proportion of diversity in these streams resulted from taxon turnover among sites. This finding was true at every spatial scale studied: within streams, among streams, and among major drainage basins. High $\beta$-diversity is an increasingly recognized attribute of large river ecosystems (Ward and Tockner, 2001), but probably is equally important in small alpine streams (Monaghan et al., 2002). Measures of diversity also were scale-dependent; some fragments had lower richness, but unique species in some fragments increased the diversity of the whole stream. A large number of rare taxa appears to be a common attribute of stream macroinvertebrate communities (Illies, 1971; Malmqvist and Hoffsten, 2000; Robinson et al., 2000). Rare taxa may be more sensitive to environmental change than common taxa (Gaston, 1994; Cao et al., 1998), making streams particularly susceptible to the effects of fragmentation. Finally, complete understanding of the role of dispersal in maintaining benthic macroinvertebrate communities in habitat fragments lags behind our knowledge of the effects of habitat alteration (but see Caudill, 2003); however, we suggest that habitat alteration was the primary cause of changes in assemblage structure in these streams. Consequently, habitat-based conservation is likely to be successful in maintaining populations of all but the weakest dispersers.

\section{Acknowledgments}

First and foremost, authors M. T. M. and C. T. R. express our appreciation for the years of guidance and mentorship provided by G. Wayne Minshall. We thank Mäggi Hieber for assistance with field sampling, along with Peter Burgherr, Christa Jolidon, Sandra Lass, Marianne Locke, David Locke, Florian Malard, Friederike Mösslacher, Marcos de la Puenta Nilsson, Karsten Rinke, Sven Schalla, Urs Uehlinger, and Monika Winder. For taxonomic identification, we thank thank Rolf Glatthaar (Simuliidae) and Christa Jolidon (Blepharaceridae). We also thank Michel Sartori and Jean-Luc Gattolliat (Ephemeroptera), Verena Lubini (Plecoptera), and Wolfram Graf and J. Waringer (Trichoptera) for their instruction and help with macroinvertebrate identification. The manuscript was improved with the comments and suggestions of David Arscott, Todd Royer, and three anonymous reviewers. Research was funded by Swiss National Science Foundation grants 3150440.97 and 31-50444.97.

\section{References}

Allan, J. D., 1995 Stream ecology: structure and function of running waters. London: Chapman and Hall. 388 pp.

Allan, J. D. and A. S. Flecker, 1993. Biodiversity conservation in running waters. BioScience 43: 32-43.
Andren, H., 1994. Effects of habitat fragmentation on birds and mammals in landscapes with different proportions of suitable habitat: a review. Oikos 71: 355-366.

Atmar, W. and B. D. Patterson, 1993. The measure of order and disorder in the distribution of species in fragmented habitat. Oecologia 96: 373-382.

Atmar, W. and B. D. Patterson, 1995. The nestedness temperature calculator: a visual basic program, including 294 presenceabsence matrices. AICS Research, Inc. University Park, New Mexico, USA, and The Field Museum, Chicago, USA.

Bauernfeind, E. and O. Moog, 2000. Mayflies (Insecta: Ephemeroptera) and the assessment of ecological integrity: a methodological approach. Hydrobiologia 423: 71-83.

Blake, J. G., 1991. Nested subsets and the distribution of birds in isolated woodlots. Conservation Biology 5: 58-66.

Boecklen, W. J., 1997. Nestedness, biogeographic theory, and the design of nature reserves. Oecologia 112: 123-142.

Bohonak, A. J. and D. G. Jenkins, 2003. Ecological and evolutionary significance of dispersal by freshwater invertebrates. Ecology Letters 6: 783-796.

Breitenmoser-Würsten, C. and M. Sartori, 1995. Distribution, diversity, life cycle and growth of a mayfly community in a prealpine stream system (Insecta, Ephemeroptera). Hydrobiologia 308: 85-101.

Brittain, J. E., 1982. Biology of mayflies. Annual Review of Entomology 27: 119-147.

Brittain, J. E. and S. J. Saltveit, 1989. A review of the effects of river regulation on mayflies (Ephemeroptera). Regulated Rivers: Research and Management 3: 191-204.

Burgherr, P. and J. V. Ward, 2000. Zoobenthos of kryal and lake outlet biotypes in a glacial flood plain. Verh. Internat. Verein. Limnol. 27: 1587-1590.

Cao, Y., D. D. Williams and N. E. Williams, 1998. How important are rare species in aquatic community ecology and bioassessment? Limnology and Oceanography 43: 1403-1409.

Caudill, C. C., 2003. Measuring dispersal in a metapopulation using stable isotope enrichment: high rates of sex-biased dispersal between patches in a mayfly metapopulation. Oikos 101: 624-630.

Douglas, M. and P. S. Lake, 1994. Species richness of stream stones: an investigation of the mechanisms generating the species-area relationship. Oikos 69: 387-396.

Downes, B. J., P. S. Lake, E. S. G. Schreiber and A. Glaister, 1998. Habitat structure and regulation of local species diversity in a stony, upland stream. Ecological Monographs 68: 237-257.

Dynesius, M. and C. Nilsson, 1994. Fragmentation and flow regulation of river systems in the northern third of the world. Science 266: 753-762.

Fahrig, L., 2003. Effects of habitat fragmentation on biodiversity. Annual Review of Ecology Evolution and Systematics 34: 487-515.

Gaston, K. J., 1994. Rarity, Chapman and Hall, London, 224 pp.

Hieber, M., C. T. Robinson, U. Uehlinger and J. V. Ward, 2002. Are alpine lake outlets less harsh than other alpine streams? Archiv für Hydrobiologie 154: 199-223.

Illies, J., 1971. Emergenz 1969 im Breitenbach. Archiv für Hydrobiologie 69: 14-59.

Klein, B. C., 1989. Effects of forest fragmentation on dung and carrion beetle communities in central Amazonia. Ecology 70: $1715-1725$.

Kling, G. W., G. W. Kipphut, M. M. Miller and W. J. O’ Brien, 2000. Integration of lakes and streams in a landscape perspective: The importance of material processing on spatial patterns and temporal coherence. Freshwater Biology 43: 477-497.

Magurran, A. E., 1988. Ecological diversity and its measurement, Croom Helm, London, 179 pp.

Malmqvist, B. and P. O. Hoffsten, 2000. Macroinvertebrate taxonomic richness, community structure and nestedness in Swedish streams. Archiv für Hydrobiologie 150: 29-54. 
Malmqvist, B., Y. X. Zhang and P. H. Adler, 1999. Diversity, distribution and larval habitats of North Swedish blackflies (Diptera : Simuliidae). Freshwater Biology 42: 301-314.

Margules, C. R., G. A. Milkovits and G. T. Smith, 1994. Contrasting effects of habitat fragmentation on the scorpion Cercophonius squama and an amphipod. Ecology 75: 20332042.

Melo, A. S. and C. G. Froehlich, 2001. Macroinvertebrates in neotropical streams: richness patterns along a catchment and assemblage structure between 2 seasons. Journal of the North American Benthological Society 20: 1-16.

Minshall, G. W., 1984. Aquatic insect-substratum relationships. In: V. H. Resh and D. M. Rosenberg (eds.), The ecology of aquatic insects, Praeger, New York, pp. 358-400.

Minshall, G. W. and C. T. Robinson, 1998. Macroinvertebrate community structure in relation to measures of habitat heterogeneity. Archiv für Hydrobiologie 141: 129-151.

Monaghan, M. T., P. Spaak, C. T. Robinson and J. V.Ward, 2001. Genetic differentiation of Baetis alpinus Pictet (Ephemeroptera: Baetidae) in fragmented alpine streams. Heredity 86: 395-403.

Monaghan, M. T., M. Hieber, C. T. Robinson, P. Spaak and J. V. Ward, 2002. Spatial patterns of Ephemeroptera, Plecoptera, and Trichoptera diversity in fragmented alpine streams. Verh. Internat. Verein. Limnol. 28: 1429-1435.

Newmark, W. D., 1991. Tropical forest fragmentation and the local extinction of understory birds in the eastern Usambara Mountains, Tanzania. Conservation Biology 5: 67-78.

Neraas, L. P. and P. Spruell, 2001. Fragmentation of riverine systems: the genetic effects of dams on bull trout (Salvelinus confluentus) in the Clark Fork River system. Molecular Ecology 10: $1153-1164$.

Patterson, B. D., 1987. The principle of nested subsets and its implications for biological conservation. Conservation Biology 1: 323-334.

Patterson, B. D. and W. Atmar, 1986. Nested subsets and the structure of insular mammalian faunas and archipelagos. Biological Journal of the Linnean Society 28: 65-82.

Poff, N. L., 1997. Landscape filters and species traits: towards mechanistic understanding and prediction in stream ecology. Journal of the North American Benthological Society 16: 391-409.

Richards, C., R. J. Haro, L. B. Johnson and G. E. Host, 1997. Catchment and reach-scale properties as indicators of macroinvertebrate species traits. Freshwater Biology 37: 219-230.

Richardson, J. S. and R. J. Mackay, 1991. Lake outlets and the distribution of filter-feeders: an assessment of hypotheses. Oikos 62: $370-380$.

Ritter, D. F., R. C. Kochel and J. R. Miller, 1995. Process geomorphology, 3rd edition. W.C. Brown Publishers, Dubuque, Iowa, USA, $539 \mathrm{pp}$.

Robinson, C. T. and G. W. Minshall, 1990. Longitudinal development of macroinvertebrate communities below oligotrophic lake outlets. Great Basin Naturalist 50: 303-311.
Robinson, C. T., G. W. Minshall and T. V. Royer, 2000. Inter-annual patterns in macroinvertebrate communities of wilderness streams in Idaho, U.S.A. Hydrobiologia 421: 187-198.

Robinson, G. R., R. D. Holt, M. S. Gaines, S. P. Hamburg, M. L. Johnson, H. S. Fitch and E. A. Martinko, 1992. Diverse and contrasting effects of habitat fragmentation. Science 257: 524-526.

Sartori, M. and P. Landolt, 1999. Atlas de distribution des éphémères de Suisse (Insecta, Ephemeroptera), Centre Suisse de Cartographie de la Faune, Neuchâtel, 214 pp.

Saunders, D. A., R. J. Hobbs and C. R. Margules, 1991. Biological consequences of ecosystem fragmentation: a review. Conservation Biology 5: 18-32.

Sponseller, R. A., E. F. Benfield and H. M. Valett, 2001. Relationships between land use, spatial scale and stream macroinvertebrate communities. Freshwater Biology 46: 1409-1424.

Tachet, H., P. Richoux, M. Bournaud and P. Usseglio-Polatera, 2002. Invertébrés d'eau douce. CNRS Éditions, Paris, 588 pp.

Taylor, C. M. and M. L. Warren, Jr., 2001. Dynamics in species composition of stream fish assemblages: environmental variability and nested subsets. Ecology 82: 2320-2330.

Vinson, M. R., 2001. Long-term dynamics of an invertebrate assemblage downstream from a large dam. Ecological Applications 11: 711-730.

Voelz, N. J., and J. V. McArthur, 2000. An exploration of factors influencing lotic insect species richness. Biodiversity and Conservation 9: 1543-1570.

Ward, J. H., 1963. Hierarchical grouping to optimize an objective function. Journal of the American Statistical Association 58: 236.

Ward, J. V., 1976. Comparative limnology of differentially regulated sections of a Colorado mountain river. Archiv für Hydrobiologie 78: $319-342$.

Ward, J. V., 1994. Ecology of alpine streams. Freshwater Biology 32: $277-294$.

Ward, J. V. and J. A. Stanford, 1979. The ecology of regulated streams. Plenum, New York, 398 pp.

Ward, J. V. and K. Tockner, 2001. Biodiversity: towards a unifying theme for river ecology. Freshwater Biology 46: 807-819.

Waringer, J. A. and W. Graf, 1997. Atlas der österreichischen Köcherfliegenlarven: unter Einschluss der angrenzenden Gebiete, Facultas Universitätsverlag, Wien (Vienna), 286 pp.

Wilcox, B. A. and D. D. Murphy, 1985. Conservation strategy: the effects of fragmentation on extinction. American Naturalist 125: 879-887.

Willis, T. V. and J. J. Magnuson, 2000. Patterns in fish species composition across the interface between streams and lakes. Canadian Journal of Fisheries and Aquatic Sciences 57: 1042-1052.

Wright, D. H., B. D. Patterson, G. M. Mikkelson, A. Cutler and W. Atmar, 1998. A comparative analysis of nested subset patterns of species composition. Oecologia 113: 1-20.

Zar, J. H., 1999. Biostatistical analysis, $4^{\text {th }}$ edition, Prentice-Hall, Englewood Cliffs, New Jersey, 663 pp.

Zwick, P., 1992. Stream habitat fragmentation - a threat to biodiversity. Biodiversity and Conservation 1: 80-97. 


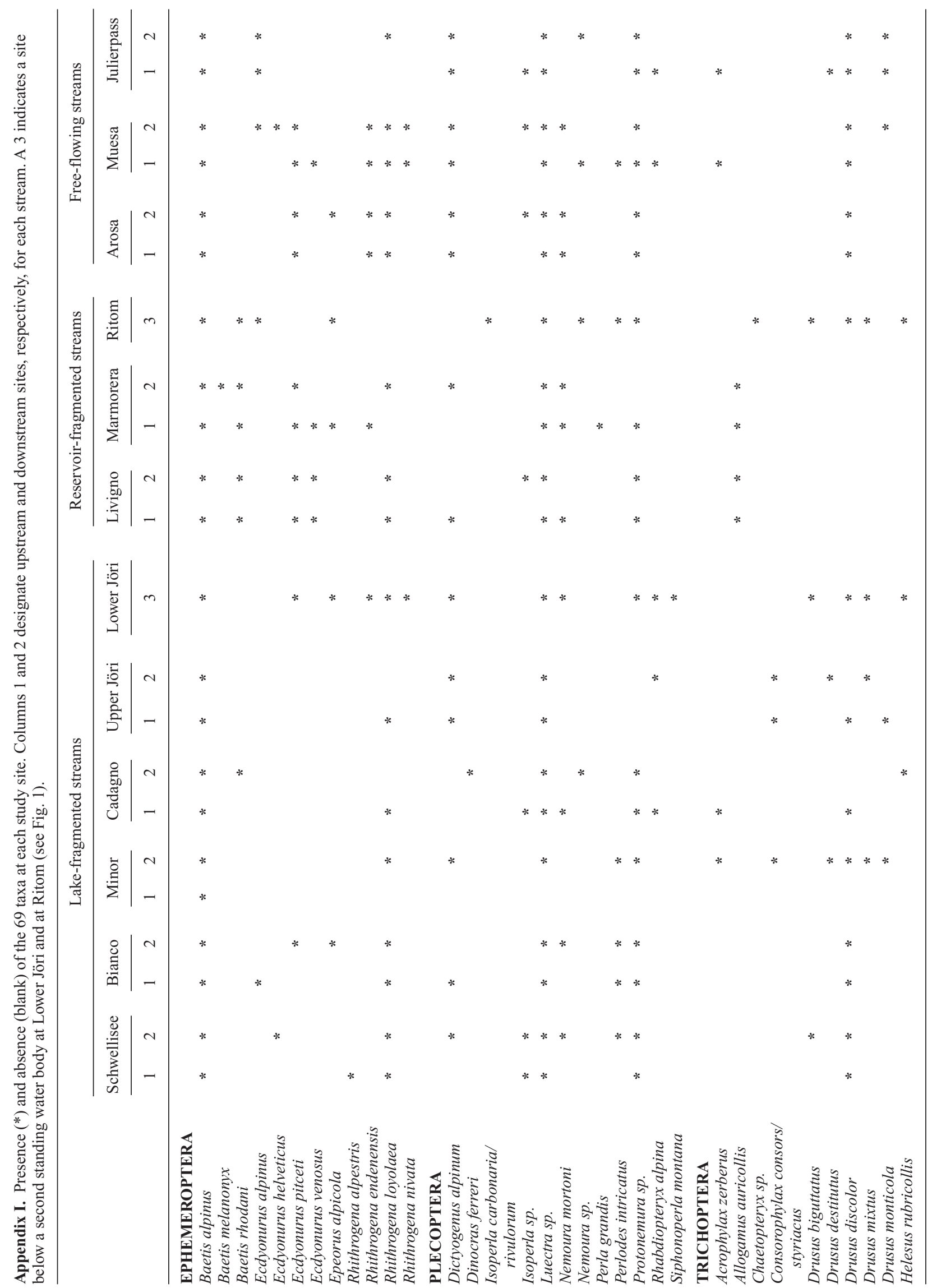




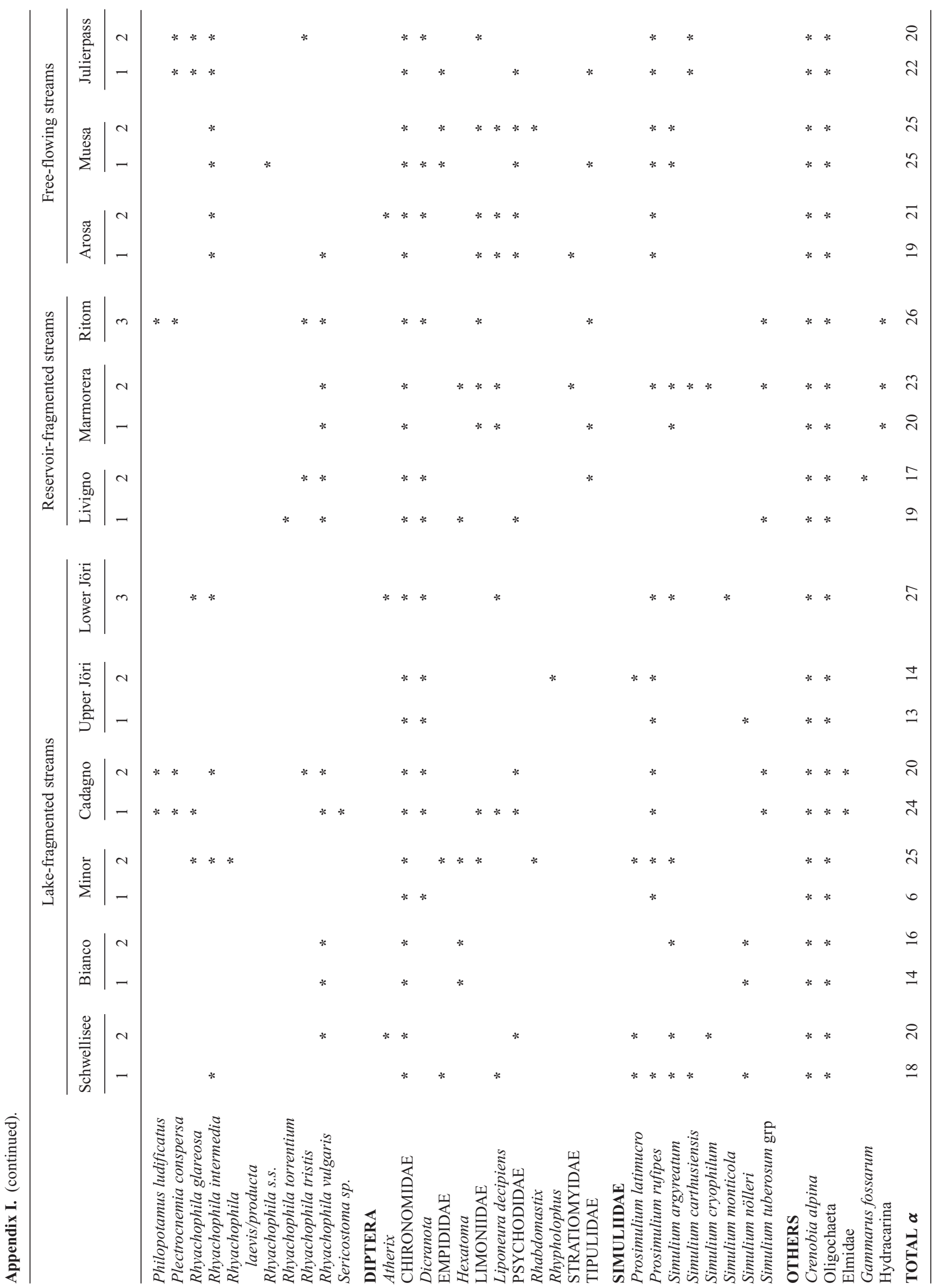

